Katarzyna Szymczyk

Uniwersytet Warszawski

\title{
SYSTEM WYBORCZY, CZYNNE PRAWA WYBORCZE I ROLA ELEKTORATU W ISLAMSKIEJ REPUBLICE
}

\section{Wstęp}

Celem niniejszego opracowania jest przeanalizowanie istoty systemu wyborczego oraz roli elektoratu w Iranie pod względem teoretycznych przesłanek tegoż systemu w sprzeczności do faktycznego znaczenia i przełożenia głosów elektoratu na irańską polityczną rzeczywistość. Postawiono hipotezę, iż zamierzenie stworzenia państwa odwzorowującego strukturę republiki opartej na zasadzie suwerenności społecznej oraz trójpodziale władzy w przypadku Iranu nie zyskało odzwierciedlenia w rzeczywistości i formy sprawowania władzy od początku przypominają w dużej mierze autokrację, a ściślej hierokrację, co pozwala uzasadnić stwierdzenie, iż irańska republika jest republiką jedynie z nazwy. W konsekwencji, autorka niniejszego opracowania podejmuje się uzasadnienia prawidłowości, iż znaczenie przeprowadzania wyborów i oddawania głosów na przedstawicieli do parlamentu i na prezydenta $\mathrm{w}$ Iranie jest $\mathrm{w}$ gruncie rzeczy mało istotne, gdyż władza w praktyce wybiera się sama, a czynne prawo wyborcze jest jedynie ze strony elektoratu manifestem podtrzymywania nostalgicznego ducha demokracji. Artykuł o charakterze poglądowym opracowano na drodze przestudiowania i przeanalizowania dostępnej literatury naukowej odnoszącej się do systemu politycznego w Iranie, artykułów prasowych, portali internetowych o tematyce irańskiej, pozycji poruszających zagadnienia z obszaru nauki o systemach politycznych, religioznawstwa, badań dotyczących kultury i obyczajowości społeczeństwa irańskiego, a w szczególności kwestii obejmujących problematykę szyizmu. 


\section{Geneza powstania i struktura ustroju politycznego Islamskiej Republiki Iranu}

Iran, dokładnie Irańska Republika Islamska, jak sama nazwa wskazuje jest republiką, której ustrój zapisany w konstytucji opiera się na władzy przedstawicieli wybranych przez naród na czas określony ${ }^{1} \mathrm{w}$ pośrednich lub bezpośrednich wyborach, ${ }^{2}$ islamską, bowiem w państwie obowiązuje prawo muzułmańskie, szyickie, odwołujące się do zasad zapisanych w Koranie, czyli szariat. Rola religii w Republice Islamskiej jest zdecydowanie dominująca, a znaczenie kościoła jako instytucji jest równie decydujące. ${ }^{3}$ Do 1979 roku Iran był monarchią konstytucyjną, w której władzę pełnił szach, a władza ta była praktycznie absolutna. Strukturę państwa tworzyły trzy organy: ustawodawcza, wykonawcza i sądownicza, a monarcha stał na czele tych organów, mimo że w założeniu miały one ową wszechwładzę ograniczać. ${ }^{4}$ Przewrót społeczno-religijny w 1979 roku całkowicie zmienił ustrój i koncepcję przywódcy. Obecnie w Iranie oficjalnie na najwyższym stopniu w hierarchii państwa stoi Mahomet. Jako że nie jest to postać namacalna, to przyjęto, iż na ziemi Mahomet ma do dyspozycji swoiste dwa instrumenty do sprawowania władzy. Są to Koran i sunna Proroka jako pierwsze narzędzie i Przywódca muzułmański, jako narzędzie drugie, a którym może być wyłącznie tzw. welajat-e faghih, czyli prawnik muzułmański. W rzeczywistości państwem kieruje człowiek o bardzo szerokim spektrum prerogatyw i nieograniczonym immunitecie, który jedynie odpowiada przed Bogiem. ${ }^{5}$ Pierwszym przywódcą religijnym w nowym państwie był inicjator rewolucji islamskiej Ruhollah Chomeini, a po jego śmierci w 1989 roku prerogatywy przywódcy religijnego przejął ajatollah Ali Chamenei. Kadencja najważniejszego przywódcy trwa do końca jego żywota i jest kluczowa dla kwestii trwania islamskiej republiki. Warto w tym miejscu nadmienić, iż początkowe koncepcje nowego ustroju państwa, które zrodziły się w okresie rewolucji islamskiej pod rządami ówczesnego premiera Mehdiego Bazargana były bliższe liberalnej wizji islamskiego państwa, bardziej demokratycznego niż islamskiego z konstytucją zbudowaną na wzór z Piątej Republiki Charlesa de Gaulle'a. ${ }^{6}$ Chomeini jednak całkowicie odrzucał jakiekolwiek inicjatywy mające na celu wprowadzenie demokracji w Iranie. Wobec tego pomysł Mehdiego Bazargana, aby obywatele mogli dokonać wyboru na kartach do głosowania w referendum między Republiką Islamską a Demokratyczną Republiką Islamską dla Chomeiniego był zwyczajnie nie do zaakceptowania. Chomeini utożsamiał słowo „demokracja” lub „demokratyczny” z całym złem płynącym ze świata zachodniego. W rezultacie przegłosowano jedynie słuszną w oczach przywódcy rewolucji koncep-

\footnotetext{
Słownik Języka Polskiego PWN, http://sjp.pwn.pl/szukaj/republika.html (data dostępu: 23.12.2014 r.).

Słownik Języka Polskiego SJP, http://sjp.pl/republika (data dostępu: 23.12.2014 r.).

http://edu.gazeta.pl/edu/h/Republika+islamska (data dostępu: 23.12.2014 r.).

M. Stolarczyk, Iran. Państwo i religia, Warszawa 2001, s. 123.

Ibidem, s. 125.

E. Abrahamian, Historia współczesnego Iranu, Warszawa 2011, s. 212.
} 
cję państwa muzułmańskiego opartego na szyickim odłamie islamu, czyli pokładaniu głębokiej wiary w niepodważalny absolutyzm Allaha, w siłę proroka Mahometa, dwunastu imamów i oczekiwaniu na powrót ukrytego imama, a także na sprawiedliwości czerpanej z Koranu, na czele którego stanął welajat-e faghih. ${ }^{7}$ Nowy ustrój zaakceptowało w referendum $98 \%$ społeczeństwa, dla którego jedyną ostatecznie dostępną alternatywą na kartach do głosowania było utrzymanie niepopularnej i nietolerowanej monarchii absolutnej. W takiej sytuacji prawdopodobieństwo przegranej dla zaplecza Chomeiniego było w gruncie rzeczy niemożliwe. Islamska Republika Iranu w swej politycznej strukturze uwzględniła trójpodział władzy: jednoizbowy parlament muzułmański, tzw. Madżles, jako organ ustawodawczy, urząd prezydenta oraz radę ministrów jako organ wykonawczy, a także Sąd Najwyższy i sądy okręgowe jako organ sądowniczy. Nie sposób pominąc istotnego faktu, że sądy utraciły podział na świeckie i religijne oraz uległy silnemu procesowi reislamizacji, który całkowicie oparł instytucję sądownictwa na Koranie i poddał ją pod zwierzchnictwo kościoła. Kadencja parlamentu i prezydenta trwa cztery lata, po czym następują wybory powszechne. Od 1999 roku na drodze wyborów lokalnych tworzy się również samorządy terytorialne. Właściwie w tym miejscu kończy się charakter ustroju Iranu jako republiki, bowiem wszystko ponad to jest szeroko zakrojoną ideologią bardzo specyficzną dla tego państwa.

\section{Istota, kreacja oraz zakres prerogatyw Najwyższego Przywódcy w Iranie}

Podczas prac nad konstytucją stery kraju istotnie tkwiły w rękach Chomeiniego i poniekąd on sam zagwarantował sobie taki przebieg prac, aby w finalnym etapie najważniejsze w państwie stanowiska trafiły w ręce duchownych. Kluczową zmianą w konstytucji i strukturze władzy było przypisanie samemu Chomeiniemu miana Najwyższego Przywódcy, miana, które asygnowało szeroki wachlarz uprawnień, dzięki którym Chomeini mógł wyznaczać kierunki i wytyczne polityki w kraju, kontrolować ich realizację, mieć wpływ między innymi na decyzyjność organów wykonawczych, ustawodawczych, czy też sugerować zakres pracy sądów. ${ }^{8} \mathrm{~W}$ dużej mierze chaos, jaki panował w kraju na przełomie 1979 i 1980 roku, duch antyimperializmu, fasadowy ton rewolucjonistów oraz silna propaganda teorii welajat-e faghih sprzyjały szybkiemu wprowadzaniu zmian w konstytucji na korzyść duchowieństwa. Biorąc pod uwagę rosnące etapami antyklerykalne nastroje w kraju na przestrzeni trzech dekad trwania Islamskiej Republiki najprawdopodobniej koncepcja Chomeiniego w innej sytuacji i w państwie, na drodze racjonalnych rozważań i w okresie spokoju

A. Krasnowolska, Rewolucja 1978-1979 i Islamska Republika Iranu, (w:), Eadem (red.), Historia Iranu, Wrocław 2010, s. 885. 
wewnętrznego nie zyskałaby silnego poparcia wśród obywateli. Pierwsza najważniejsza kwestia zmian w strukturze władzy po 1979 roku w Iranie to zasada odpowiedzialności przywódcy przed narodem. We wcześniejszych latach, szach stojący na czele państwa przysięgał przed parlamentem godne wypełnianie zasad i wierność konstytucji, a tym samym pozostawał lojalny wobec narodu. Nadwyrężenie owej lojalności miało swoje konsekwencje w utracie tronu, czego przykładem jest usunięcie szacha Mohammada Ali Szah Kadżara w 1925 roku. Tymczasem pozycja Najwyższego Przywódcy została przyjęta jako praktycznie nieprzemijająca, wieczna, niezmienna i według zapisów w konstytucji Przywódca osądzany jest jedynie przez Boga, czyli de facto nie odpowiada przed narodem. ${ }^{9}$ Teoretycznie nad właściwym wypełnianiem obowiązków owego ojca duchowego narodu czuwa powołana do życia 86-osobowa izba duchownych, zwana Zgromadzeniem Ekspertów. Kadencja izby trwa osiem lat, a jej członkowie są wybierani na drodze powszechnych wyborów. Obywatele irańscy mogą zatem decydować przy pomocy kart do głosowania, jaka grupa duchownych zasiądzie w Zgromadzeniu. Tego typu wybór jest jednak w dużej mierze bardzo ograniczony, bowiem jedyne co pozostaje to alternatywa zagłosowania na duchownego nieco bardziej liberalnego i postępowego w odróżnieniu od twardogłowych konserwatystów islamskich. Taka alternatywa może wydawać się nietrafiona, bowiem każdy kandydat to osoba w rzeczywistości związana z tym samym środowiskiem, czyli kościołem. W tej sytuacji faktyczne, prawdziwe, słuszne prawo i możliwość wyboru właściwego kandydata są w dużym stopniu dyskusyjne. Szczególnie jeśli rozważyć przyjdzie istotną kwestię, że najważniejszą i decyzyjną osobę w kraju powołują na urząd właśnie duchowni w Zgromadzeniu, a zatem nie obywatele i co więcej, to duchowni weryfikują pracę Przywódcy, tudzież ewentualnie decydują o jego odwołaniu. ${ }^{10} \mathrm{Na}$ decyzję Zgromadzenia duży wpływ ma Rada Strażników Konstytucji, instytucja utworzona w celu kontrolowania zgodności prac parlamentu z zasadami islamu, a także wydawane opinie przez trzech możnych i uznanych dostojników duchownych przypatrujących się pracy Zgromadzenia. Można odnieść wrażenie, że wola narodu jest w tym przypadku całkowicie pomijana i faktycznie najważniejsze funkcje w kraju przypadają osobom $\mathrm{z}$ jednego klerykalnego kręgu. ${ }^{11}$ Podsumowując, Najwyższy Przywódca jest osobą klerykalną, wybieraną przez Zgromadzenie Ekspertów, na których głosują Irańczycy w powszechnych wyborach, ale że kandydaci są wyłącznie osobami duchownymi, to faktycznie władza pozostaje w rękach kościoła. Wybór do Zgromadzenia Ekspertów pomiędzy kandydatami będącymi wyłącznie duchownymi i brak możliwości wybierania przez obywateli osoby na stanowisko Najwyższego Przywódcy pozostają sprzeczne z za-

9 M. Stolarczyk, Iran..., op. cit., s. 125.

10 M. Piskur, System polityczny Islamskiej Republiki Iranu, (w:), Portal Spraw Zagranicznych, http://www.psz.pl/ 117-polityka/mariusz-piskur-system-polityczny-islamskiej-republiki-iranu (data dostępu: 23.12.2014 r.).

11 T. Coville, Najnowsza historia Iranu. Republika Islamska, Warszawa 2009, s. 69. 
sadami wyborczymi ustroju republiki. Nie mniej kontrowersji mogą wywoływać wybory do irańskiego parlamentu, a także funkcjonowanie sądownictwa.

\section{Paradoksalność funkcjonowania irańskiego parlamentu i sądownictwa}

Obywatele mają prawo głosować w bezpośrednich wyborach co cztery lata na kandydatów do parlamentu - Madżlesu, jedynego organu ustawodawczego w kraju. Madżles składa się z 290 członków i funkcjonuje jako jedna izba (na mocy nowej konstytucji zlikwidowano Senat), sam organizuje prace i ustanawia własny regulamin, przeto kreuje wrażenie, iż jest to organ w pełni niezależny. Madżles podlega jednak nieustannej hospitacji ze strony Rady Strażników Konstytucji. Ten już wcześniej wspomniany organ kontrolujący składa się z dwunastu członków, w tym sześciu teologów mianowanych przez Najwyższego Przywódcę i sześciu prawników wytypowanych przez Madżles z listy, którą otrzymuje od Najwyższej Rady Sądowniczej. Nad Najwyższą Radą Sądowniczą nadzór pełni sam Najwyższy Przywódca, który mianuje na prezesowskie stanowisko Najwyższego Sędziego. ${ }^{12}$ Zadaniem parlamentu jest reprezentowanie narodu i decydowanie o polityce państwa, a także kwestionowanie prac władzy wykonawczej i sądownictwa. Pojawia się tu swoiste kuriozum w kwestii sądownictwa. Parlament ma prawo stawiać pod znakiem zapytania prace organu sądowniczego, który w dużej mierze organizuje swój skład i wytyczne działania za aprobatą Najwyższego Przywódcy. ${ }^{13}$ Może zatem wyniknąć osobliwy zbieg okoliczności, gdy Najwyższy Przywódca miałby rozpatrywać skargę na organy powołane do pracy zgodnie z jego oczekiwaniami i sugestiami. To poniekąd sytuacja, w której Najwyższy Przywódca miałby rozpatrywać skargę na własne wcześniejsze decyzje. Można zatem wnioskować, iż teoretycznie wpisana w prawo i postulowana wolność Madżlesu w kwestii oceniania sądownictwa również pozostaje dyskusyjna i w gruncie rzeczy wywołuje wrażenie, że w rzeczywistości jest niewiążącym zapiskiem na papierze. Najwyższy Przywódca powołuje sędziów będących w podstawowym założeniu niezawisłymi dostojnikami, którzy są nieodwołalni i orzekają zgodnie z zasadami islamu. ${ }^{14} \mathrm{~K}$ westionowanie zatem ich pracy może się równać z sugerowaniem braku kompetencji do powoływania adekwatnych sędziów po stronie Najwyższego Przywódcy, a także do podważania słuszności boskich praw.

A. Krasnowolska, Rewolucja..., op. cit., s. 885.

E. Abrahamian, Historia..., op. cit., s. 216.

M. Piskur, System..., op. cit. 


\section{Marionetkowość funkcji prezydenta}

Sporą dozę kontrowersji może także budzić istota funkcji prezydenta w Iranie. Kandydatem na ten urząd może być zarówno świecki, jak i duchowny mężczyzna wierny islamskim zasadom, praktykujący szyita, w wieku minimum 25 lat (w 2013 roku zniesiono górną granicę wieku kandydata 75 lat). Pretendentów ostatecznie weryfikuje i zatwierdza Rada Strażników Konstytucji. Przykładowo w ostatnich wyborach w Iranie w 2013 roku na urząd prezydenta zarejestrowało swoje kandydatury 686 osób. Rada Strażników Konstytucji zaopiniowała i wyłoniła ośmiu. ${ }^{15}$ Prezydenta wybierają obywatele co cztery lata w bezpośrednim głosowaniu. Wybory mogą zakończyć się już po pierwszej turze, a jeśli większością głosów nie zdoła się wybrać żadnej osoby, to następuje druga tura, w której biorą udział dwaj kandydaci z najwyższymi wynikami w turze pierwszej. Urzędujący prezydent po upływie czterech lat może tylko raz ponownie ubiegać się o fotel. W odróżnieniu od większości państw o ustroju uwzględniającym urząd prezydenta, w Iranie osoba na tym stanowisku nie jest uznawana jako najważniejsza w kraju, nie ma statusu przewodnika kraju, bowiem podlega bezpośrednio pod zwierzchnictwo Najwyższego Przywódcy. Wątpliwa zatem wydaje się ta funkcja w państwie jako organ wykonawczy. Najwyższy Przywódca albo zatwierdza osobę wybraną przez obywateli na fotel prezydenta lub całkowicie jej nie akceptuje, takie uprawnienia mu przysługują, lecz jeśli akceptacja nastąpi, to niestety nie gwarantuje ona niezależności prezydenta od Najwyższego Przywódcy, bowiem wypełnianie obowiązków przez prezydenta jest nieustannie hospitowane przez welajat-e faghiha. Prezydent to nie pierwsza, lecz druga najważniejsza i wpływowa osoba w kraju. Każda decyzja prezydenta odnośnie powoływania ministrów musi być poparta przez Madżles i Najwyższego Przywódcę. Posunięcia prezydenta w kwestiach związanych z Radą Ministrów, którą tworzy po zlikwidowaniu w 1989 roku funkcji premiera, powoływanie wiceprezydenta, proponowanie z rządem reform, kreowanie planów politycznych, strategii i umów międzynarodowych jest opiniowane, weryfikowane i popierane lub negowane przez Najwyższego Przywódcę. ${ }^{16} \mathrm{O}$ ile konsultacje z parlamentem i zabieganie o poparcie pośród parlamentarzystów w interpelacjach dotyczących kierunków polityki i mianowania ministrów są zrozumiałe i zgodne z zakresem działania prezydenta, to procedura uzyskiwania akceptacji u zwierzchnika duchownego jest specyficzna i wywołuje kolejne wątpliwości odnośnie sensowności utrzymywania tego urzędu w wymownie klerykalnym ustroju w Iranie.

\footnotetext{
15 U. Pytkowska, Kampania prezydencka w Iranie ruszyła pełną parą, (w:), Solidarni z Iranem, http://solidarniziranem.pl/pl/publicystyka/item/209-kampania-prezydencka-w-iranie-ruszyla-pelna-para-urszula-pytkowska (data dostępu: 30.12.2014 r.). 
System wyborczy, czynne prawa wyborcze i rola elektoratu w Islamskiej Republice

\section{Irracjonalność ustroju politycznego i systemu wyborczego w Iranie}

Rozważając najważniejsze aspekty ustrojowe konstytucji i porównując je z rzeczywistością można dojść do wniosku, iż hybryda republiki opartej na systemie wyborczym w Iranie i jednocześnie występujące cechy państwa hierokratycznego, a wręcz autorytarnego, to sztuczny twór pozbawiony logiki. Z jednej strony Iran funkcjonuje jako państwo, w którym istnieją prawidłowości, iż władza pochodzi od ludu. Obywatele wybierają członków parlamentu, prezydenta, przedstawicieli do lokalnych rad i oczywiście duchownych do Zgromadzenia Ekspertów. Procedury są jasne i podkreślają wagę głosów wyborców. Prawo wyborcze przypada w udziale zarówno kobietom, jak i mężczyznom od ukończenia szesnastego roku życia (do 2005 roku obowiązywał wiek 15 lat). Z drugiej strony decyzje wyborcze elektoratu są poddawane kontroli, która z kolei jest thumaczona jako przejaw troski o dobro narodu, wszak sam Chomeini otwarcie twierdził, iż ,jest słuszne, że najwyższe autorytety duchowne kontrolują pracę prezydenta czy innych wysokich oficjeli państwowych, by mieć pewność, że nie popełniają błędów czy też nie występują przeciwko prawu i Koranowi". ${ }^{17}$ Mamy zatem kontrolę i zwierzchnictwo dostojników kościelnych nad prezydentem, parlamentem, a także sądownictwem. Trzy organy z trójpodziału władzy podlegają w rzeczywistości jednej osobie. Ponadto w zakresie prerogatyw Najwyższego Przywódcy jest również mianowanie prezesa Rady do spraw Radia i Telewizji, przewodnictwo nad siłami zbrojnymi i siłami bezpieczeństwa, a także nad Armią Strażników Rewolucji - siłą paramilitarną powołaną do kontrolowania społeczeństwa, aby przestrzegało norm i kodeksu islamskiego obowiązującego nie tylko w polityce, ale i w codziennym życiu obywateli. ${ }^{18}$ Cały system polityczny w Iranie przypomina dyktaturę jednej centralnej partii komunistycznej połączoną z osobliwym zjawiskiem boskiego lidera, który posiada władzę mocniejszą niż król, czy szach. Obywatelom podarowano prawo wyborcze, które w istocie nie ma żadnego przełożenia na rzeczywistość. Już w pierwszych latach umacniania struktur Irańskiej Republiki, Chomeini wykreował swoją osobę na postać Duce i niezmiernie skutecznie zwalczał antyislamskie i sprzeczne z jego wizją wystąpienia przeciwników, dyskusje i rozważania. Jakiekolwiek protesty i zgromadzenia brutalnie tłumiono, przeprowadzano czystki na uczelniach i w ośrodkach naukowych, zamykano kłopotliwe redakcje prasowe i wprowadzono moralny kodeks postępowań dla kobiet i mężczyzn, który sprawnie począł ograniczać wolności obywatelskie. ${ }^{19}$ Narodem zastraszanym, izolowanym od reszty świata i silnie indoktrynowanym wszak łatwiej jest administrować i przy tym nietrudno utrzymać władzę absolutną, czego dowodem mogą być przykłady wieloletnich reżimów w innych

E. Abrahamian, Historia..., op. cit., s. 214.

A. Krasnowolska, Rewolucja..., op. cit., s. 885.

N.R. Keddie, Współczesny Iran. Żródła i konsekwencje rewolucji., Kraków 2007, s. 245. 
częściach globu. Rola elektoratu w wyborach w przypadku Iranu jest swoistą absurdalnością, takie prawo jest zwyczajnym irrealizmem i społeczeństwo wydaje się być tego w pełni świadome. Od końca lat osiemdziesiątych ubiegłego wieku można w Iranie zaobserwować tendencję w narodzie do negacji wybitnie hierokratycznego ustroju. Wizja państwa w ciągłym regresie wywoływała ogromne niezadowolenie w społeczeństwie. Rządy do 2005 roku tworzyli ludzie wybrani ze względu na ich znaczną pragmatyczność w polityce i bardziej liberalne podejście do obywateli. Naród oczekiwał swobód, wolności słowa, otwarcia się państwa na Zachód i modernizacji. Stopniowo usiłowano oddalać się od klerykalnego wymiaru państwa i to w zasadzie od momentu śmierci Chomeiniego w 1989 roku. ${ }^{20}$ Postępujący nurt reformatorski w Iranie zaobserwowany w latach dziewięćdziesiątych ubiegłego wieku i na początku XXI wieku był sprzeczny z interesami duchownych i tradycjonalistów, którzy tłumili wszelkie ruchy i manifestacje prozachodnie, wolnościowe gazety, sprzeciwy wobec obowiązującego kodeksu postępowań. W tym czasie można było zaobserwować, jak bardzo naród, zwłaszcza młody elektorat wyrażał otwartą niechęć wobec brodatych włodarzy w turbanach. Niestety, po 2005 roku, po wygranej w wyborach prezydenckich Mahmuda Ahmadineżada konserwatysty w obozie życzliwym dla Najwyższego Przywódcy Chamenei ponownie w kraju umocniła się pozycja duchownych. W istocie rok 2005 stał się na osi czasu symbolicznym momentem powrotu Iranu na drogę chomeinizmu, umacniania się doktryny islamskiej i utrzymywania polityki mocno zachowawczej. W takiej sytuacji, szanse na zmianę ustroju na rzeczywiście republikański są w istocie jałowe. Pozycja kościoła w Iranie jest zbyt silna i zbyt mocno zakorzeniona w tradycji, obyczajowości, gruntownie wpojona $\mathrm{w}$ świadomość wielu obywateli, u wielu tłumiąca nadzieje na zmiany. Przełożenie religii na politykę jest tak wielkie, że rzesze ludzi uosabiają Najwyższego Przywódcę jako zesłannika Proroka i próba jego obalenia byłaby walką z samym Bogiem. Swoisty paradoks polega na tym, iż jednocześnie funkcjonuje silne przekonanie i potrzeba utrzymywania państwa w statucie republiki, nawet jeśli jest to swoista parodia republiki. Naród pomimo relewantnej świadomości, że państwem rządzi wyłącznie kler z własnej nieprzymuszonej woli chętnie celebruje kampanie wyborcze i czynnie oraz licznie oddaje swój głos w każdych wyborach. Według relacji Polskiej Agencji Prasowej (PAP) frekwencja wyborcza w Iranie podczas wyborów parlamentarnych w 2008 roku wyniosła 55,4\%, a w 2012 roku liczyła 64\%. ${ }^{21}$ Według statystyk frekwencja w takich wyborach średnio oscyluje w granicach 50$70 \%$. Skoro głosowanie nie jest obowiązkowe i władze nie wymuszają na obywatelach pójścia do urn i jednocześnie wynik wyborów nie odzwierciedla prawdziwości oddanych głosów, jest bardzo przewidywalny i zazwyczaj wygraną przypisuje się osobie akceptowanej przez Najwyższego Przywódcę, a parlament podlega bezustan- 
nej hospitacji, to nasuwa się przypuszczenie, iż tak rozbudowany system wyborczy w Iranie jest nieautentycznym, irracjonalnym tworem ustrojowym manipulującym elektoratem, pozostaje ceremonią bez mocy sprawczej. Dla wielu bardzo prawdziwe i adekwatne jest stwierdzenie niejako definiujące system wyborczy w Iranie, iż jest to państwo, „w którym od tego, kto jak glosuje, ważniejsze jest - jak zauważyt kiedyś w odniesieniu do innych realiów Józef Stalin, kto liczy głosy". ${ }^{22} \mathrm{~W}$ tym miejscu tkwi poniekąd potrzeba wyjaśnienia i usprawiedliwienia irracjonalności systemu wyborczego w Iranie pod kątem roli elektoratu. W kraju, w którym panuje welajat-e faghih niczym Orwellowski Wielki Brat, czynne prawo wyborcze, akt głosowania podtrzymuje wśród obywateli ducha demokratyzmu, wolności, samostanowienia, jest postulatem poważania elektoratu, sposobem komunikowania się z przywódcami, krzewieniem prawdy, iż naród irański nie pozostanie obojętny na działanie władz. Duch demokracji, który głosi, iż władza jest w rękach ludu chroni obywateli przed całkowitym zniewoleniem.

\section{Uwagi końcowe}

W 2014 roku minęło 35 lat od proklamowania Islamskiej Republiki Iranu. W fotelu prezydenta od 2013 roku zasiada Hasan Rouhani. Uważany za umiarkowanego kleryka, jako pierwszy od czasów Chomeiniego przeprowadził telefoniczną rozmowę z prezydentem Stanów Zjednoczonych, mocarstwa, z którym Iran nie utrzymuje stosunków dyplomatycznych od 1979 roku. Nowy prezydent zapowiedział otwarcie się Iranu na świat. W kwestiach społecznych wewnątrz kraju pozostaje nadal zachowawczy. Pomimo tego, kolejny prezydent to kolejna nadzieja, że wybrany przez naród człowiek nie będzie marionetką Najwyższego Przywódcy i znajdzie odwagę oraz chęci, by wsłuchać się w postulaty i apelacje większości elektoratu i wyprowadzi kraj na ścieżki bardziej demokratyczne, mniej klerykalne, mniej radykalnie islamskie.

\section{BIBLIOGRAFIA}

Abrahamian, E., Historia współczesnego Iranu, Warszawa 2011

Coville T., Najnowsza historia Iranu. Republika Islamska, Warszawa 2009

Keddie N. R., Współczesny Iran. Źródła i konsekwencje rewolucji, Kraków 2007

Krasnowolska A., (red.), Historia Iranu, Wrocław 2010

Polska Times, http://www.polskatimes.pl/artykul/522423,iran-64procentowa-frekwencja-w-wyborach-parlamentarnych,id,t.html?cookie=1, 30.12.2104 


\section{Katarzyna Szymczyk}

Portal Spraw Zagranicznych, http://www.psz.pl/117-polityka/mariusz-piskur-system-polityczny-islamskiej-republiki-iranu, 23.12.2014

Solidarni z Iranem, http://solidarniziranem.pl/pl/publicystyka/item/209-kampania-prezydencka-w-iranie-ruszyla-pelna-para-urszula-pytkowska, 30.12.2014

Stolarczyk, M., Iran. Państwo i religia, Warszawa 2001

http://edu.gazeta.pl/edu/h/Republika+islamska, 23.12.2014 


\section{ELECTORAL SYSTEM, ACTIVE VOTING RIGHTS AND THE ROLE OF THE ELECTORATE IN THE ISLAMIC REPUBLIC OF IRAN}

This study examines the constitution of the Islamic Republic of Iran, its electoral system and the active voting rights of Iranian citizens. The article illustrates the dichotomy between constitution and reality in which the role of the electorate and the casting of votes at polls, gives the impression of being pointless as all final decisions in the country require approval of the clergy and elected representatives in parliament are subject to the authority of the Supreme Leader. The author analyzes the meaning of the electoral system and the electoral law and studies the phenomena of very high electoral frequency.

Keywords: Iran, right to vote, electorate, president, parliament, clergy

Słowa kluczowe: Iran, prawo wyborcze, elektorat, prezydent, parlament, duchowni 